\title{
O UCZCIWYM OBIEKTYWIZMIE, CZYLI JAK PISAĆ O POLAKACH I UKRAIŃCACH
}

\section{tUKASZ ADAMSKI,}

POSTEEPOWY NACJONALISTA.

MYCHAJtO HRUSZEWSKI

I JEGO POGLACYY

NA POLSKE I POLAKÓW

Lukasz Jasina

Wyższa Szkoła Stosunków Międzynarodowych

i Komunikacji Społecznej w Chełmie

Od odzyskania niepodległości przez Polskę i Ukrainę minęły już dwie dekady - to dużo, jeśli brać pod uwagę chociażby egzystencję II RP czy też znacznie krótsze istnienie niegdysiejszych ukraińskich tworów państwowych.

Jeśli ktoś zdecydowałby się na podliczenie wydanych w tym czasie publikacji dotyczących stosunków polsko-ukraińskich na różnych ich etapach - zarówno dotyczących przeszłości, teraźniejszości, jak i wieszczących, co przydarzy się za lat kilka lub kilkanaście - dałoby się prawdopodobnie zasłać nimi drogę z Warszawy do Kijowa. Lektura wielu z nich prowadzi do ważnej konstatacji - Polacy i Ukraińcy najlepiej potrafią pisać o historii - będącej wciąż najważniejszym wyznacznikiem wzajemnych relacji. Pisanie o historii jest jednak przedsięwzięciem znacznie trudniejszym niż snucie na poły amatorskich wizji politologicznych. Dobre dzieło historiograficzne winno być przede wszystkim produktem rzetelnej pracy i intelektualnej skromności. W dobie pełnej autorów pełnych pasji i misji do spełnienia o rzetelność nawet w tym zawodzie trudno. Jeszcze trudniej odnaleźć publikacje pełne nie tylko rzetelności, ale i myślowej głębi. 
Niezwykle jasnym punktem w grupie ukazujących się ostatnio polskich i ukraińskich książek o naszej wspólnej historii okazuje się najnowsza publikacja Łukasza Adamskiego. I choć nie jest to właściwie książka o Polsce i Ukrainie, a o największym ukraińskim historyku - Mychajle Hruszewskim - to stanowi jedno z lepszych podsumowań konfliktów i stereotypów, jakie do dziś wpływają na relacje między dwoma narodami.

\section{/// O historyku}

Główny bohater książki Adamskiego, Mychajło Hruszewski, to historyk-symbol. Jego pomniki znajdują się w Kijowie, Lwowie (na miejscu dawnego monumentu poświęconego Aleksandrowi Fredrze) i innych miastach współczesnej Ukrainy. O Hruszewskim pisze się dziś na Ukrainie dużo - niegdyś przodowała w tym emigracja. Jego imię nosi zreszta katedra historii Harvard Ukrainian Research Institute w Cambridge - którą zajmowali Omelijan Prytsak, Roman Szporluk czy Serhii Płohij. Hruszewskiego - tworzącego wszak aż do śmierci w ZSRR - nigdy nie usunięto również z panteonu naukowego radzieckiej Ukrainy, a po roku 1991 pozycja naukowca stała się niepodważalna. Jego autorska koncepcja przedstawiona w nieukończonym, wielotomowym dziele: Historia Ukrainy-Rusi, oddziałuje na współczesną ukraińską politykę historyczną. Wpływy Hruszewskiego można odnaleźć w dziele Leonida Kuczmy, Ukraina to nie Rosja, i w koncepcjach Wiktora Juszczenki. Hruszewski inspiruje również Polaków, z którymi przez całe życie walczył zarówno jako naukowiec, jak i polityk. Ukraina. Narodżiny Narodu (2004-2007) Jerzego Hoffmana wyraźnie przyjmuje koncepcje Hruszewskiego za trafne. Hruszewski stworzył koncepcję dziejów Ukrainy wyraźnie odróżniająca ją od Rosji czy Rzeczypospolitej. To istniejące od tysiąca lat państwo i naród nieroztapiające się w „Wielkiej Rusi” czy „ruskiej” części Korony, Wielkiego Księstwa Litewskiego i ich kolejnego stadium Rzeczypospolitej Obojga Narodów.

\section{// / Nacjonalista postępowy}

Hruszewski Adamskiego to „postępowy nacjonalista”. Z jednej strony jest niezwykle nowoczesnym naukowcem, zna wiele języków, podróżuje po świecie i żyje w sposób niezwykle „światowy”. Pełny jest zrozumienia dla lewicowych teorii społecznych i wie, że nadciaga rewolucja. Z drugiej strony jest jednak nacjonalista. Esencją i osią myślenia są zawsze dla niego Ukraina i Ukraińcy. Dla tego celu jest w stanie podpisać pakt z „diabłem” (co czyni pod koniec życia). Gdy rozprawia o sprawach narodowych, jego 
postępowość nie ma znaczenia. Tego typu myślenie to na Ukrainie częsty przypadek. Tak można opisać chociażby system myślowy Iwana Franki ${ }^{1}$.

Ten oto „postępowy nacjonalista” jest patronem obecnej ukraińskiej historiografii. Nie wiem, czy bylibyśmy w Polsce szczęśliwi, mając na sztandarach Joachima Lelewela pomieszanego z Romanem Dmowskim. Czasem miewam wrażenie, że tradycji nie należy odrzucać, ale nacjonalizm warto zastapić patriotyzmem. Ważnym uzupełnieniem polskiej tradycji narodowej może być rozszerzenie jej o wielokulturowe elementy. Uważam, że „polskość” to nie tylko piastowscy książęta, ale i Jagiellonowie. To nie tylko ludowe pieśni polskich chłopów z okolic Opoczna, ale i łemkowskie cerkiewki czy hasydzkie tańce. Moim zdaniem - Ukraina będąca obszarem stworzonym przez przedstawicieli wielu kultur i narodów nie jest „Ukrainą-Rusią” Hruszewskiego. Czcząc Hruszewskiego jako ojca historiografii ukraińskiej, jednocześnie uznaje się jego bardzo już zacofana koncepcję za prawdziwą. Hruszewski jest kimś w rodzaju Tukidydesa czy Długosza - szanując go, należy przejść do dzieł nowatorskich.

Z drugiej strony, zastanawia i każe wysnuwać własne wnioski zawarta w tytule sprzeczność. Czy we współczesnym świecie - zwalczającym wszelkiego rodzaju „nacjonalizmy” i lansującym „postępowość” - możliwe jest ich zestawienie? Polska publicystyka dotykająca spraw ukraińskich wykazywała daleko posuniętą akceptację dla elementów nacjonalizmu silnych na Ukrainie - potępiając jednocześnie każdą rodzimą prawicowość. Wielu autorów nawoływało do wyrozumiałości dla polityki historycznej Wiktora Juszczenki - choć jednocześnie potępiało hołd oddawany „żołnierzom wyklętym”. Czy dla każdego „nacjonalisty” przyjmowano te same kryteria?

\section{/// Polacy i Ukraińcy}

Hruszewski urodził się w mieszanym narodowo mieście - Chełmie, mieszkał również w polskiej Łomży. Kijów czasów jego studiów to miasto pełne Polaków. Jego mentorem był człowiek wychowany w kulturze polskiej, a on sam najlepsze uniwersyteckie lata spędził we Lwowie, zderzając się z żywotnością kultury zachodniego sąsiada. Jako badacz posługiwał się często językiem polskim, a znajomości tego języka wymagał od swoich uczniów w radzieckim Kijowie.

\footnotetext{
${ }^{1}$ Szerzej: Jarosław Hrycak, Prorok we własnym kraju. Iwan Franko i jego Ukraina (1856-1886), przeł. Anna Korzeniowska-Bihun i Anna Wylegała, Wydawnictwo Krytyki Politycznej, Warszawa 2010 oraz w recenzji: L. Jasina, Galicyjskie reminiscencje, [w:] Kultura Liberalna, nr 135 (32/2011) z 9 sierpnia $2011 \mathrm{r}$.
} 
Monografia Adamskiego i dokładny opis biografii jej bohatera każa nam się zastanowić nad jego stosunkiem do Polski i Polaków. Z jednej strony, był badaczem rzetelnym, nie stronił od kontaktów ze środowiskami polskimi (zwłaszcza na początku pobytu we Lwowie), znał polską literaturę naukową i był przez Polaków czytywany i recenzowany. Z drugiej, jego działalność polityczna doprowadziła go do konfliktu z Polakami, rzec można - nieuchronnego. W ówczesnym świecie koncepcje Hruszewskiego i jego polskich poprzedników nie mogły się spotkać z akceptacją.

Już w latach 20. ostry stosunek do polskiej dominacji na Ukrainie prowadził Hruszewskiego do kompromisu z reżimem - wkrótce odpowiedzialnym za ludobójstwo.

W recenzji (do jej fragmentu może zajrzeć każdy, oglądając okładkę książki) pracy Adamskiego historyk Jerzy Borejsza porównuje rolę odegrana przez Hruszewskiego z rolą wspomnianego Lelewela. Porównanie wydaje się trafne - choć nie do końca. Ich koncepcje historiograficzne były w dużej mierze podobne. Obydwaj mieli też cel wyższy od pisania historii obiektywnej - stworzenie lub utrwalenie historii swojego narodu. Inna sprawa, że Lelewel nie jest już od dawna patronem historiografii polskiej, jego pomniki zniknęły ze skwerów polskich miast, jego dorobek zaś jest już raczej obiektem akademickich wykładów niż rozpalających intelektualnie dyskusji społecznych.

Podobieństwo Lelewela i Hruszewskiego rysuje się ponadto w ich karierze politycznej. W wypadku pierwszego kończą ją nieudane powstanie i działalność emigracyjna. Hruszewski wieńczy ją współpraca z jednym z zaborców, co kładzie się cieniem na całej jego biografii.

Związki Hruszewskiego z Polską to wiele etapów i sytuacji. Przychodzi na świat w Chełmie - w rodzinie nauczyciela-rusyfikatora. Chełmszczyzna jest wtedy miejscem ważnym. Za chwilę nastapi kasata unii i wzmoże się nacisk rusyfikacyjny. Wydarzenia te staną się elementem polskiego mitu Chełmszczyzny, w którym Rusini unici zostaną wyniesieni na ołtarze bojowników polskości. Jednocześnie będą się budować mity rosyjskie i ukraińskie. Miejsce, w którym Hruszewski dość przypadkowo przyjdzie na świat, będzie arena największego konfliktu polsko-ukraińskiego i jest nim w pewnym sensie do dziś. Tablica upamiętniająca Hruszewskiego nie jest we współczesnym Chełmie miejscem jednoczącym, lecz dzielącym.

Wychowywany na różnych kresach imperium - Hruszewski podejmuje studia na Uniwersytecie Kijowskim. Jego mistrz, prof. Wołodymyr Antonowicz, był szlachcicem wychowanym w polskiej kulturze - który dokonał samodzielnego wyboru narodowego, stając się Ukraińcem. Jego 
młody uczeń miał, według niego, zostać naukowcem budującym mosty pomiędzy Polakami i Ukraińcami. Zaprotegowany do objęcia katedry na uniwersytecie we Lwowie Hruszewski podczas spędzonych tam dwóch dekad staje się niestrudzonym przeciwnikiem polskości i polskiej dominacji w Galicji. Jakże często nadzieja pojednania doprowadzała do pogłębienia konfliktu.

Po raz trzeci (choć nigdy do końca jej nie zarzucił) Hruszewski podejmuje działalność naukowa po przyjeździe na Ukrainę radziecką. Tutaj przerywa ja stalinowska walka z efektami korzystnej dla Ukrainy polityki narodowościowej na przełomie lat 20. i 30. Rosja i Ukraina są dla niego mniejszym złem niż Polska. I choć Hruszewskiego pochowa się na koszt państwa i z pewnymi honorami, to swoją walkę chwilowo przegra. I przegraja ją Ukraińcy.

Winniśmy pamiętać o tym, że w momencie kryzysu naszych stosunków - w chwili gdy dzieło Giedroycia i Osadczuka, Ihora Szewczenki i Romana Szporluka upada - pojednanie między naszymi narodami traci swój impet.

W pewnym sensie Wiktor Juszczenko był słabszym intelektualnie następcą Hruszewskiego. Też miał się stać symbolem pojednania, ale polityka doprowadziła go do czegoś skrajnie odmiennego. Znowu muszę odwołać się do własnych wrażeń i przekonań - miłość do narodu jest wartościa wspaniałą. Należy go jednak kochać umiejętnie - inaczej jest to miłość tragiczna. Sposób Hruszewskiego już się nie sprawdza.

\section{/// Pułapka fałszywego obiektywizmu}

Zajmując się analizą autorskiej narracji, zapominamy o tym, jak duże znaczenie mają czasem: bibliografia i przypisy - tutaj czynią one z książki podręczne kompendium stosunków polsko-ukraińskich w dobie przełomu. Podobnie ma się sprawa z licznymi dygresjami. Zaburza to przejrzystość wywodu - ale zwiększa wartość merytoryczną publikacji. Ladunek informacyjny jest dla historyka ważniejszy niż kryształowa przejrzystość następujących po sobie wątków. Historia jest wszak nauką humanistyczną.

Hruszewskiego szanowano za umysł i niepodważalny talent. Adamski cytuje polskich badaczy oddających mu hołd, ale jednocześnie przypominających jego nieskrywaną wrogość wobec polskich koncepcji. Autor Postępowego nacjonalisty... nie popełnia błędów historyków sprzed wieku. Jego analiza biografii Hruszewskiego jest rzetelna. Pisze ją historyk, a nie polityk, człowiek pełen pasji odkrywczej, a nie manipulator.

Adamski dowodzi, że najlepszym sposobem na opisywanie dziejów jest po prostu uczciwość i wykorzystywanie narzędzi, jakie daje metodologia 
dyscypliny. Na szczęście w Polsce i na Ukrainie tacy historycy są i z każdym rokiem jest ich więcej.

Z drugiej strony, autor dowodzi, że nie jest fetyszysta „obiektywizmu”. Wiemy wszyscy bardzo dobrze, że pełny obiektywizm nie istnieje. Wizja Adamskiego jest wizja polskiego historyka. Polski dystans umożliwia mu spojrzenie na Hruszewskiego bez fałszywej czołobitności, acz jednocześnie bez nieuzasadnionej krytyki. Dowodzi to tego, że polska nauka historyczna posunęła się nieco do przodu od czasów Lelewela.

Obowiązkiem recenzenta jest znalezienie słabej strony. Takie praca Adamskiego ma. Tu i ówdzie myli jakieś szczegóły. Są miejsca, gdzie eseista zbyt wyraźnie wygrywa z naukowcem, a pasjonat z badaczem. Jako i recenzujący, i recenzowany - uważam jednak, że wypominanie niewielu detali nie ma sensu, gdy całość jest udana, a autorowi udała się konstrukcja i jej wypełnienie - oraz co nie mniej ważne - stworzenie monografii historycznej, której czytanie wnosi coś do współczesnego dyskursu.

Jej lektura to obowiązek każdego Polaka mieniącego się znawca polskiej polityki zagranicznej. Niestety, ciagle zbyt wielu jest takich, którzy myślą, że wiedza, a nie wiedzą zgoła nic - powtarzają jedynie wyuczone formułki wywodzace się ze zwulgaryzowanych idei Giedroycia i Osadczuka. Może dokładna lektura dzieła Adamskiego pomoże im wejść na drogę zrozumienia cokolwiek skomplikowanych dziejów dusz Polaków i Ukraińców.

Bibliografia:

/// Adamski, Lukasz. 2011. Postępony Nacjonalista. Mychajto Hruszenuski i jego poglady na Polskę i Polaków. Warszawa: Wydawnictwo Naukowe PWN.

/// Hrycak, Jarosław. 2010. Prorok we własnym kraju. Iwan Franko ijego Ukraina (1856-1886). Przeł. A. Korzeniowska-Bihun i A. Wylegała. Warszawa: Wydawnictwo Krytyki Politycznej.

/// Jasina, Lukasz. Galicyjskie reminiscencje. W: „Kultura Liberalna” nr 135 (32/2011) z 9 sierpnia $2011 \mathrm{r}$. 